\title{
Employability Skill Gap Analysis of Commerce Postgraduate Students in Higher Education With Reference To Coimbatore District
}

\author{
Dr. M. Jegadeeshwaran \\ Assistant Professor, \\ Department of Commerce, \\ Bharathiar University, Coimbatore, \\ Tamilnadu, India
}

\author{
Kaleeshwari. S \\ M.Phil. Research Scholar, \\ Department of Commerce \\ Bharathiar University, \\ Coimbatore, Tamilnadu, India
}

\begin{abstract}
The Indian education system is completely transforming into capability-based training to get into fruitful output. The educational companies are aware of improving and changing the world for Indian's persisted competitiveness to face the aggressive market. Even though there is wide and high quality filled education the proportion of well-skilled candidates are comparatively low, which is a big task for the employers and the corporates to meet its requirements. Dynamism as a whole lot injected because of this education couldn't impart the establishment for a regular solution. The competencies gap in enterprises and the postgraduate students are getting widened due to many reasons, each from the part of an enterprise and the candidate. This paper focuses on the above-mentioned critics and the important employability skills that students have and where they lag which creates a gap in them. A skill gap between actual and expected was identified from the findings and the influence of skill and the difference of skills availability among male and female students, it would be an eye-opener for the educations programme to focus on providing skills in which the lag is identified. The findings of this paper say that the students are highly equipped with ICT\& interpersonal skills and business skills with the highest loading and other important skills must also be given importance.
\end{abstract}

\section{Keywords}

Employability, Life Skills, Skillset, Skill gap, Factors influencing.

\section{INTRODUCTION}

Today's global economy is fast-paced, highly competitive demands educated citizens who possess many skills such as soft and hard skills. This demand is affected by several trends and challenges one such is the development of ICT the fast-growing information and communication technology that is hard for people to adapt to. Employers are demanding advanced communication skilled candidates for the future. The $21^{\text {st }}$ century students finding it hard to quickly adapt to a new business environment with high tech $21^{\text {st }}$-century skills. Educational institutions feel skills are very much essential for the student's life for setting career or civic sense [1]. The task is to equip students with the necessary skills and critical thinking skills to forester creative drive. It is because the talent problem of employer and employee are twined together. Society says higher education especially management education as a stepping stone for a good lucrative job. So, the difficulties in attaining skills along with knowledge must be concentrated by the institutions where it can perform more activities to develop the students in the respective soft skills and hard skills [2][3].

\subsection{Important Skills}

The employability skills are been classified into three main heads[4]:

$$
\begin{aligned}
& \text { 1.1.1 Soft skills } \\
& \text { - } \text { People Related Skills } \\
& \text { - } \text { Interpersonal Skills } \\
& \text { - } \text { Teammunication Skills } \\
& \text { - } \text { Personal Skills } \\
& \text { - } \text { Flexibility } \\
& \text { - } \text { Leadership Skills } \\
& \text { - } \text { Professionalism } \\
& \text { - } \text { Vork Ethics } \\
& \text { - } \text { Sociantarism Responsibility }
\end{aligned}
$$

1.1.2 Hard skills

- Technical skills

- Knowledge in a specialized area

- $\quad$ Critical thinking/ problem solving

- Analytical thinking

- Planning \& organizing

- Decision making

- $\quad$ ICT skills

\subsubsection{Business skills}

- Dealing with real-world problems

- Creative thinking/innovation

- Global business scenario

- Multilateral thinking

1.2 Government Initiated Programme for Skills Development among Students

- Pradhan Mantri Kaushal Vikas yojana initiated to benefit 10 million youths- ministry of skill development and entrepreneurship

- The National Skill Development Corporation India (NSDC)[5] 


\section{Statement of the Problem}

In the dynamic competitive world, the employer expects to graduate with a range of skills and attribute at various levels, but the graduate now with pass percentage and degree doesn't match their scale of expectation. There is a huge gap in employability skills. There is a vast difference between employable skills and the skills provided by educational institutions. It is very much important for a student to equip themselves with skills along with life skills which are very much necessary for life as well as o get an appropriate job. Now a day's lack of certain skills among young students has become a hurdle in attaining a proper job set. The study aims to analyze the skills gap of postgraduate students to find out the level of skills and what are all skills that must be imparted in the learning process along with the academics.

\subsection{Objectives of the Study}

- To analyze the employability skill gap of the commerce postgraduate students.

- To identify the factors influencing the skills of the students.

- $\quad$ To find the significant difference in the level of skill availability between male and female students.

\subsection{Hypothesis}

- There is no significant influence on the skills of commerce postgraduate students.

- There is no significant difference in the skills availability between female and male students.

\section{Research Methodology}

The study is descriptive:

\subsection{Source of data}

This study is based on primary data. The data are collected from respondents using a questionnaire.

\subsection{Sampling design}

The random sampling method is adopted to collect the data from 300 students pursuing post-graduate concerning the Coimbatore district.

\subsection{Tools used for the study}

The data is analyzed using statistical tools like Factor analysis, regression, correlation and one-way Anova.

\section{Analysis and Interpretation}

Table 1: Demographic Characteristics of Respondents

\begin{tabular}{|l|l|l|l|l|}
\hline $\begin{array}{l}\text { Sc. } \\
\text { no }\end{array}$ & Characteristics & Category & Frequency & \% \\
\hline 1 & AGE & $21-24$ & 300 & 100 \\
\hline \multirow{2}{*}{2} & \multirow{2}{*}{ GENDER } & MALE & 140 & 46.6 \\
\cline { 3 - 5 } & & FEMALE & 160 & 53.4 \\
\hline \multirow{2}{*}{3} & \multirow{2}{*}{ DOMICILE } & URBAN & 215 & 71.6 \\
\cline { 3 - 5 } & & RURAL & 85 & 28.4 \\
\hline
\end{tabular}

Source: Primary Data

Above table 1 shows the demographic characteristics of respondents. The entire respondents are in the age category of 21-24. $46.6 \%$ of the respondents are male and $53.6 \%$ are female, 71.6 of the respondents are from urban and 28.4 are from the rural population.

\subsection{Reliability test}

The above table shows the Cronbach value of reliability. It can be concluded that all the variables are reliable due to each value of the variable are greater than 0.7 which is acceptable

Table 2: Reliability Statistics

\begin{tabular}{|l|l|l|}
\hline Cronbach's Alpha & $\begin{array}{l}\text { Cronbach's Alpha } \\
\text { Based on } \\
\text { Standardized Items }\end{array}$ & N of Items \\
\hline .789 & .953 & 56 \\
\hline
\end{tabular}

Table 3: KMO and Bartlett's Test

\begin{tabular}{|l|l|l|}
\hline Kaiser-Meyer-Olkin Measure of Sampling Adequacy. & $\mathbf{. 7 3 1}$ \\
\hline \multirow{3}{*}{ Bartlett's Test of Sphericity } & Approx. Chi-Square & 8919.022 \\
\cline { 2 - 3 } & Df & 300 \\
\cline { 2 - 3 } & Sig. & $\mathbf{. 0 0 0}$ \\
\hline
\end{tabular}

Factors Analysis

The above table shows the KMO results where the statistic value is .731 which is well above the minimum criterion of .5 and falls into the range of 'middling'. So, the sample size is adequate for factor analysis. And Bartlett's test for sphericity shows .000 which is significant to conduct further tests. The analysis of the principal component and rotated factor loading method is used to identify the factors. It is observed that out of 15 variables, 5 factors namely ICT skills \& Interpersonal skills, business skills, personal skills, decision making \& communication skills and person-related skills were identified by the rotation method. In the study, items that had a loading of -+.5 or greater were retained. To analyze the impact of the listed dimensions on the opinion of the beneficiaries, the first step involved was reducing the number of statements to a smaller number of variables which could be then used for factor analysis

Table 4: Factor 1- ICT and Interpersonal Skills

\begin{tabular}{|l|l|l|}
\hline Label & Statement & Loadings \\
\hline X48 & $\begin{array}{l}\text { I can interact with others and complete } \\
\text { tasks on time }\end{array}$ & .801 \\
\hline X37 & I have Analytical thinking skills & .785 \\
\hline X44 & I have high sense of direction & .734 \\
\hline X38 & I am familiar with word processing & .717 \\
\hline X25 & I am a good at being resourceful & .688 \\
\hline X55 & I work with voluntarism & .648 \\
\hline X45 & I can manage/do several tasks at once & .603 \\
\hline
\end{tabular}

Source: IBM SPSS

Table 5 shows the cluster of statements in factor 1 the statement "Interact with Others" with the loading of .801, "Analytical Thinking" with the loading of .785, "High Sense of Direction" with .734, "Word Processing" with .717, "Being Resourceful" with .688, 
"Voluntarism" with .648, "Manage/Do Several Tasks With" .603 are grouped in the first factor.

Table 5: Factor 2- Business Skills

\begin{tabular}{|l|l|l|}
\hline Label & Statement & Loadings \\
\hline X7 & $\begin{array}{l}\text { I have good attendance, be on time and } \\
\text { dress up appropriately. }\end{array}$ & .829 \\
\hline X57 & I focus on Social responsibility & .817 \\
\hline X56 & I have Work ethics & .741 \\
\hline X58 & I do all the work with Professionalism & .689 \\
\hline X3 & I listen and ask a question to understand & .629 \\
\hline
\end{tabular}

\section{Source: IBM SPSS}

Table 6 shows the cluster of statements in factor 2 the statement "Good Attendance" with the loading of .829, "Social Responsibility" with the loading of .817, "Work Ethics" with .741, "Professionalism" with .689, "Listen and Ask Question" with .629 are grouped in a factor

\section{Table 6: Factor 3- Personal Skills}

\begin{tabular}{|l|l|l|}
\hline Label & Statement & Loadings \\
\hline X9 & $\begin{array}{l}\text { I can accept and apply criticism to improve my } \\
\text { work }\end{array}$ & .784 \\
\hline X2 & $\begin{array}{l}\text { I can read and understand the information in } \\
\text { words, graphs, diagrams, or charts }\end{array}$ & .739 \\
\hline X14 & $\begin{array}{l}\text { I can combine ideas or information in a new } \\
\text { way. }\end{array}$ & .701 \\
\hline X24 & $\begin{array}{l}\text { I am good at taking initiative and making } \\
\text { decisions }\end{array}$ & .618 \\
\hline
\end{tabular}

\section{Source: IBM SPSS}

Table 7 shows the cluster of statements in factor 3 the statement "Accept and Apply Criticism" with the loading of .784, "Read and Understand Information" with the loading of .739, "Combine Ideas or Information" with .701, good at taking initiative with .618, are grouped in the factor

Table 7: Factor 4- Decision Making and Communication Skills

\begin{tabular}{|l|l|l|}
\hline Label & Statement & Loadings \\
\hline & & \\
\hline X16 & I can make decisions on my own & .836 \\
\hline X1 & $\begin{array}{l}\text { I can speak and write clearly so that others } \\
\text { understand }\end{array}$ & .781 \\
\hline X6 & I have basic math skill & .746 \\
\hline
\end{tabular}

Source: IBM SPSS

The coefficient for the influence of skills for employability shows that ICT \& interpersonal skills, business skills and people related skills are below 0.05 level of significance which means we reject the null hypothesis saying students are influenced by the above three skills.
Table 8 shows the cluster of statements in factor 4 the statement "Make Decisions" with the loading of .836, "Speak and Write Clearly" with the loading of .781, "Basic Math Skill" with .746, are grouped in the factor.

Table 8: Factor 5- Person Related Skills

\begin{tabular}{|l|l|l|}
\hline Label & Statement & Loadings \\
\hline X50 & $\begin{array}{l}\text { I can deal with difficult people and } \\
\text { situation }\end{array}$ & .876 \\
\hline
\end{tabular}

\section{Source: IBM SPSS}

Table 9 shows the cluster of statements in factor 5 the statement "Deal with Difficult People" is grouped in the last factor.

Table 9: Model Summary

\begin{tabular}{|l|l|l|lr|l|}
\hline Model & $\mathrm{R}$ & R Square & $\begin{array}{l}\text { Adjusted } \\
\text { Square }\end{array}$ & $\begin{array}{l}\text { Std. Error of the } \\
\text { Estimate }\end{array}$ \\
\hline 1 & $.423^{\mathrm{a}}$ & .179 & .165 & .42336 \\
\hline
\end{tabular}

Table 10: Coefficients

\begin{tabular}{|c|c|c|c|c|c|}
\hline \multirow[t]{2}{*}{ Model } & \multicolumn{2}{|c|}{$\begin{array}{l}\text { Unstandardized } \\
\text { Coefficients }\end{array}$} & \multirow{2}{*}{\begin{tabular}{|c|}
$\begin{array}{l}\text { tandardized } \\
\text { fficients }\end{array}$ \\
Beta \\
\end{tabular}} & \multirow[t]{2}{*}{$\mathrm{t}$} & \multirow[t]{2}{*}{ Sig. } \\
\hline & B & Std. Error & & & \\
\hline \multirow{6}{*}{\begin{tabular}{|l} 
(Constant) \\
I\& ITC \& \\
Interpersonal \\
Business skills \\
Personal skills \\
pecision making \\
mmunication skills \\
People related \\
skills
\end{tabular}} & 1.690 & .024 & & 69.14 & .000 \\
\hline & .115 & .024 & .248 & 4.698 & .000 \\
\hline & .083 & .024 & .179 & 3.385 & .001 \\
\hline & .038 & .024 & .082 & 1.550 & .122 \\
\hline & .030 & .024 & .064 & 1.208 & .228 \\
\hline & -.126 & .024 & -.273 & -5.160 & .000 \\
\hline
\end{tabular}

Above table 9 results model summary for the impact of skills on the gender of postgraduate students. Gender is the dependent variable, $\mathrm{R}=0.423$ which means there is a normal relationship. $\mathrm{R}$-square is $17.9 \%$ variance from the independent variables.

\section{One-Way Anova}

$\mathrm{Ho}=$ There is no significant difference in the skills availability between female and male students.

Table 11: ANOVA

\begin{tabular}{|c|c|c|c|c|c|c|}
\hline & & $\begin{array}{l}\text { Sum of } \\
\text { Squares }\end{array}$ & $\mathrm{df}$ & $\begin{array}{l}\text { Mean } \\
\text { Square }\end{array}$ & $\mathrm{F}$ & Sig. \\
\hline ICT \& & $\begin{array}{l}\text { Between } \\
\text { Groups }\end{array}$ & 18.430 & 1 & 18.430 & 19.575 & .000 \\
\hline $\begin{array}{l}\text { Interpers } \\
\text { onal }\end{array}$ & $\begin{array}{l}\text { Within } \\
\text { Groups }\end{array}$ & 280.570 & 298 & .942 & & \\
\hline & Total & 299.000 & 299 & & & \\
\hline & $\begin{array}{l}\text { Between } \\
\text { Groups }\end{array}$ & 9.571 & 1 & 9.571 & 9.854 & .002 \\
\hline $\begin{array}{l}\text { Business } \\
\text { skills }\end{array}$ & $\begin{array}{l}\text { Within } \\
\text { Groups }\end{array}$ & 289.429 & 298 & .971 & & \\
\hline & Total & 299.00 & 299 & & & \\
\hline $\begin{array}{l}\text { Personal } \\
\text { skills }\end{array}$ & $\begin{array}{l}\text { Between } \\
\text { Groups }\end{array}$ & 2.006 & 1 & 2.006 & 2.013 & .157 \\
\hline
\end{tabular}




\begin{tabular}{|c|c|c|c|c|c|c|}
\hline & $\begin{array}{l}\text { Within } \\
\text { Groups }\end{array}$ & 296.99 & 298 & .997 & & \\
\hline & Total & 299.00 & 299 & & & \\
\hline \multirow{3}{*}{$\begin{array}{l}\text { Decision } \\
\text { making } \\
\& \\
\text { commun } \\
\text { ication } \\
\text { skills }\end{array}$} & $\begin{array}{l}\text { Between } \\
\text { Groups }\end{array}$ & 1.220 & 1 & 1.220 & 1.221 & .270 \\
\hline & $\begin{array}{l}\text { Within } \\
\text { Groups }\end{array}$ & 297.78 & 298 & .999 & & \\
\hline & Total & 299.00 & 299 & & & \\
\hline \multirow{3}{*}{$\begin{array}{l}\text { People } \\
\text { related } \\
\text { skills }\end{array}$} & $\begin{array}{l}\text { Between } \\
\text { Groups }\end{array}$ & 22.239 & 1 & 22.23 & 23.94 & .000 \\
\hline & $\begin{array}{l}\text { Within } \\
\text { Groups }\end{array}$ & 276.76 & 298 & .929 & & \\
\hline & Total & 299.00 & 299 & & & \\
\hline
\end{tabular}

Source: IBM SPSS

The results of one-way ANOVA states that the significant value of ICT \& Interpersonal skills, business skills and people related skills are below 0.05 . Hence, the null hypothesis is rejected and it can be concluded that there is a significant difference between male and female students in respect of ICT \& Interpersonal skills, business skills and people related skills.

\section{Finding and Suggestion}

- The regression analysis shows that there is an influence of skills on both male and female students

- Both male and female postgraduate students are influenced by ICT and interpersonal skills, business and people related skills. Expect personal and decision and communication skills doesn't influence them they differ from person to person.

- The one-way ANOVA shows that there is a difference between ICT \& interpersonal skills, business and people related skills on gender. This means there is a difference among male and female students in the level of skill set availability.

- One-way ANOVA also states that there is no difference between decision making \& communication skills and personal skills, which means that both male and female students pose with an equal level of skill sets.

\section{Suggestion}

- The skills which are found lag must be focused on and trained according to by the education institutions.

- Apart from the 5 skills analyzed in the paper, there are other skills such as subjective skills, time management skills and critical and creative thinking skills that are found missing.

- $\quad$ Subjective skills and time management skills can only be imparted by educational institutions where strict time management and better subject and high domain knowledge be provided with regular tests conducting quiz on current affairs related to a particular domain.

- The government-initiated programme is provided to certain criterion students at course centre situated at a particular area, it can be initiated in educational institutions also where all the students can get skill development from grass route level.

- the skill-developing programme can be separately conducted by educational institutions every week so that students may get regular up-gradation.
- Educational institutions must also send students to workshops and conference which brings a wide range of new environment and helps to develop themselves.

- Students must also be given regular training on the aptitude to increase their analytical skills and critical thinking power.

\section{CONCLUSION}

The global world is found much more competitive year by year, it is been challenging for the young generation as well as the educational institutions to provide the students with the necessary employability skills. Graduates tend to fail just because of the skill gap. The expected and actual levels of skill available differ which creates the difficulty for the students to find an apt job for them .it is the responsibility of the institutions to proactively adapt to the changes in the environment and provide with skill up-gradation regularly. Both soft skills and hard skills must be initiated as a session and regular development must be analyzed. From the study, we can conclude that even though students are well equipped with necessary business and ICT \& interpersonal skills they are insufficient in many more employability skills, so educational institutes must make note of it and take efforts to produce students with all the necessary skills along with govt schemes and proper in-hand training. In Upcoming days with proper training students will be with enhancing skills.

\section{REFERENCE}

[1] Srivastava, A. and A. Hasan. "Bridging the Skill Gap in India: Challenges and Solutions, International Journal of Scientific Research in Science and Technology 1 (2015): 318-329

[2] J.Kavitha, N. Sumathi, Employability Skill Gap Analysis Among the Engineering Students and Industry Expectation in Chennai with Structural Equation Model, International Journal of Innovative Technology and Exploring Engineering (IJITEE) ISSN: 2278-3075, Volume-8, Issue-7C2, May 2019

[3] Vikhe Gautam V, 2 Preethi Agrawal, "Industry-Institute Employability Skill Gap Analysis", ISSN (Print): 23195479, Volume-3, Issue-4, 2014

[4] Mr. Hansel Furtado, A Study on Impact of Skill Development at Entry Level Job Candidates in India, IOSR Journal of Business and Management (IOSR-JBM) e-ISSN: 2278-487X, p-ISSN: 2319-7668

[5] A Gap Analysis of Business Students' Skills in the 21st Century: A Case Study of Qatar, Academy of Educational Leadership Journal, Volume 22, Issue 1, 2018 